\title{
IRENEUSZ NOWAK
}

University of Łódź

inowak@wpia.uni.lodz.pl

ORCID: 0000-0002-7997-6887

\section{MAGDALENA DOMINIAK}

Fiscal Administration Chamber in Łódź

magdalena_dominiak@wp.pl

ORCID: 0000-0002-6909-3802

\section{Court-Appointed Physician Act - selected legal aspects}

\section{Ustawa o lekarzu sądowym \\ - wybrane aspekty prawne}

\begin{abstract}
The article is devoted to selected problems related to the performance of the activities of a court-appointed physician. Without a doubt legal regulations currently in force must be subjected to selective "legal correction" as the CourtAppointed Physician Act - passed more than 12 years ago - "in its present form" is one of the causes of the "disability" of the Polish system of justice. The Authors of the publication formulated both de lege lata and de lege ferenda postulates in this area, considering, among others the information obtained from the presidents of regional courts in Poland.
\end{abstract}

Keywords: physician; court-appointed physician; certificate; taxation; district court; civil proceedings; criminal proceedings. 
Streszczenie. Artykuł poświęcony jest wybranym problemom prawnym związanym z wykonywaniem czynności lekarza sądowego. Bez wątpienia obowiązujące unormowania prawne muszą być poddane selektywnej „korekcie prawnej”, ponieważ ustawa o lekarzu sądowym - uchwalona ponad 12 lat temu - „w obecnej formie” stanowi jedną z przyczyn „niesprawności” polskiego wymiaru sprawiedliwości. Autorzy publikacji sformułowali w tym zakresie postulaty zarówno de lege lata, jak i de lege ferenda, biorąc pod uwagę m.in. informacje uzyskane od prezesów sądów okręgowych w Polsce.

Słowa kluczowe: lekarz; lekarz sądowy; zaświadczenie; opodatkowanie; sąd okręgowy; postępowanie cywilne; postępowanie karne.

\section{Introductory remarks}

The objective of this publication is first, to determine selected legal aspects related to the performance of court-appointed physicians' activities, and then - the legal essence and a "character" of the certificates issued by court-appointed physicians who confirm an ability or inability of the parties as a result of illness to appear at court, following summons or to notify the authorized judicial bodies. However, to properly implement the above mentioned research issues, it was first necessary to correctly "decode" the purpose and the legal status of a court-appointed physician in accordance with the statutory regulation of 15 June 2007 on the courtappointed physician ${ }^{1}$. For this purpose, the subject of the research was supplemented with information obtained from the presidents of Polish regional courts concerning, among other matters, the practicalities of the contracts concluded with court-appointed physicians.

\section{The legal status of a court-appointed physician}

The Act on court-appointed physicians regulates the conditions and procedure of an appointment and a dismissal for the performance of court-

Act of 15 June 2007 on the court-appointed physician (Dz.U. [Polish Journal of Laws] of 2007, No 123, poz. [item] 849 with subsequent amendments). 
appointed physician's duties, the rules for the performance of courtappointed physician's activities, and the financing rules ${ }^{2}$. The ratio legis of the act on court-appointed physicians comes down to cases relating to a justification of an absence due to the illness of the parties, their legal representatives, attorneys, witnesses, defendants, defence lawyers, and other participants in the proceedings relating to the summons or notice of the court or the body conducting criminal proceedings, referred to as the "authorised bodies", in proceedings conducted pursuant to the Act of 6 June $1997^{3}$ Polish Criminal Proceedings Code ${ }^{4}$ and the act of 17 November 1964 Polish Civil Proceedings Code ${ }^{5}$. It should also be noted that ensuring the smooth progress of civil and criminal proceedings by providing reliability to medical certificates presented by the participants justifying their absence due to illness, is the obvious purpose of the act on courtappointed physicians. Nota bene the above legislation also introduces uniform principles for justification of an absence of participants from, in particular court proceedings, throughout the country ${ }^{6}$.

Any physician who jointly fulfils the following conditions may become a court-appointed physician: has a licence to practice the medical profession in Poland; has full legal capacity; has not been convicted of an offence or a tax offence; is of good repute; has obtained the recommendation of the regional medical council; has the title of a specialist or the first or second degree specialization ${ }^{7}$. It should be remembered, however, that the function of a court-appointed physician is dependent, as "it provides additional powers inherently related to basic powers in the field of practice of a medical or dental profession. Thus, the essence of a court-

Article 1 item 1 of Act on the court-appointed physician.

Act of 6 June 1997 the Code of Criminal Proceedings (consolidated text: Dz.U. of 2018, poz. 1987 with subsequent amendments).

4 Article 1 item 2 act on the court-appointed physician.

5 Act of 17 November 1964 the Code of Civil Proceedings (consolidated text: Dz.U. of 2019, poz. 1460 with subsequent amendments).

6 Justification of the government bill on the court-appointed physician of 27 March 2007, form 1568, http://orka.sejm.gov.pl/Druki5ka.nsf/wgdruku/1568.

7 Article 5 item 1 of Act on the court-appointed physician. 
appointed physician cannot be analysed without reference to the physicians' status in general"».

In order to ensure an access to a court-appointed physicians in an area of a jurisdiction of a district court, the district court president determines their number and concludes contracts on the performance of a court-appointed physician's activities ${ }^{9}$. It is also worth noting that district courts are created for an area of a jurisdiction of at least two regional courts, called the "court district" ${ }^{10}$. In accordance with Article 20 point 1 of Act of 27 July 2001 on the general courts system, on 28 December 2018 the Minister of Justice issued an ordinance on the establishment of seats and areas of jurisdiction for courts of appeal, district courts and regional courts and the scope of cases to be examined by them ${ }^{11}$. There are currently 45 district courts ${ }^{12}$.

The court-appointed physician issues certificates in places, on days, and within hours determined on a basis of a contract on the performance of the court-appointed physician's activities, confirming an ability or inability to appear in court, or to notify members of the authorized body of participants in the proceedings about the illness, within the area of jurisdiction of the given district court, after prior personal examination of the participant in the proceedings and after familiarising himself or herself with the available medical documentation ${ }^{13}$. However, if the medical condition of the participant in the proceedings makes it impossible for him or her to appear for the medical examination, the court-appointed physician conducts the examination and issues a certificate at the place of

8 K. Flaga-Gieruszyńska, A. Klich, Ustawa o lekarzu sqdowym. Komentarz 2013, (Komentarz do art. 1), Lex/el.

9 Articles 2-3 of Act on the court-appointed physician.

10 Article $10 \S 2$ of Act of 27 July 2001 on the general courts system (consolidated text: Dz.U. of 2019, poz. 52 with subsequent amendments).

11 Ordinance of the Minister of Justice of 28 December 2018 on establishment of seats and jurisdiction areas of the courts of appeal, district and regional courts, and the scope of cases considered by them (Dz.U. of 2018, poz. 2548 with subsequent amendments).

12 G. Artymiak, Sq̨dy okręgowe [in:] P. Hofmański, Z. Kwiatkowski (eds), System Prawa Karnego Procesowego. Tom V. Sądy i inne organy postępowania karnego 2015, Lex/el.

13 Article 2 item 2, 11-12 item 1 of Act on the court-appointed physician. 
stay of such person ${ }^{14}$. However, if the participant in the proceedings is in a hospital, a hospice, or in another healthcare institution designed for people whose health condition requires providing constant health services in a properly furnished, permanent room, the court-appointed physician may issue a certificate on the basis of an available documentation, without personal examination of the participant in the proceedings, indicating the cause for abstaining from personal examination in the certificate ${ }^{15}$.

The comments presented in the above lead to a general observation, according to which the court-appointed physician is an entity empowered to justify an absence due to illness on the occasion of a summons from a court or to notify the court or the authority conducting, among others, civil $^{16}$ or criminal ${ }^{17}$ proceedings. Thus the court-appointed physician, handling the so-called medical service of court meetings ${ }^{18}$, not only attests to the health condition of the summoned person, but also assesses whether the confirmed illness actually prevents an appearance without violation of right to health protection guaranteed by Article 68 paragraph 1 of the Polish Constitution ${ }^{19}$. A contrario, the request of a potential patient not related to the ongoing criminal or civil proceedings cannot be the basis for the issue of a certificate by a court-appointed physician, because, as it is stipulated in Article 13 of the Court-Appointed Physician Act, the certificate may be issued upon presentation of a summons or notification and presentation of an identity document to an authorized body or after sub-

14 Article 12 item 3 of Act on the court-appointed physician.

15 Article 12 item 4 of Act on the court-appointed physician.

16 "In addition, in enforcement proceedings the activities of a court-appointed physician are provided for in article $1058 \S 2$ of the Code of Civil Proceedings, because if the court imposed a fine on the debtor as a coercive measure, and the debtor did not pay the fine, the court converts the fine to arrest, and then orders its execution. In this case, the debtor can defend himself with poor health, which must be demonstrated by the certificate issued by the court-appointed physician” - K. Knoppek, Dowód z opinii biegłego [in:] T. Ereciński, T. Wiśniewski (eds), System Prawa Procesowego Cywilnego. Tom II. Część II. Postępowanie procesowe przed sq̨dem pierwszej instancji 2016, Lex/el.

17 Compare M. Kurowski, Komentarz do art. 117 k.p.k. [in:] D. Świecki (ed.), Kodeks postępowania karnego. Tom I. Komentarz aktualizowany 2019, Lex/el.

18 K. Knoppek, Dowód..., Lex/el.

19 Compare with the decision of the Appeal Court in Kraków of 14 May 1992, II AKz 95/92, Lex/el. 
mission of a declaration of receipt of summons or notification. So considering the indications that "the subject criterion, that limits the powers of the court-appointed physician to justify the absence due to illness in the event of conduct defined” ${ }^{20}$ in Article 1 item 2 of the Court-Appointed Physician Act there are no grounds to apply this provision also to confirm the reasons indicating the existence of obstacles in carrying out procedural activities, including submitting the application in writing and delivering judgment justification within a specified deadline ${ }^{21}$.

Summarizing the above considerations one should also recognize that court-appointed physicians as sui generis "adjuvants" of the legal protection bodies according to article 1 item 2 of the Court-Appointed Physician Act are under legal protection analogous to that of public servants ${ }^{22}$, however only when performing activities related to issuing of certificates pursuant to article 2 paragraphs 2-3 of the Court-Appointed Physician Act.

\section{Legal and evidential force of certificates issued by court-appointed physician}

A certificate issued by a court-appointed physician is a document ${ }^{23}$ stating, in a manner binding the court, circumstances that are essential for the conduct of criminal and civil proceedings, that is the inability of the parties to the proceedings to appear before the court or other competent authority ${ }^{24}$. However, the authority authorized (the court or the body conducting criminal or civil proceedings) may perform checks required to verify the reliability of the certificate issued by the court-appointed physician and, if in doubt as to their reliability, to promptly notify the president of the appropriate district court, the prosecutor's office, and the regional medical council ${ }^{25}$. Despite the fact that in accordance with the principle of

\footnotetext{
K. Flaga-Gieruszyńska, A. Klich, Ustawa..., (Komentarz do art. 1), Lex/el. Decision of the Supreme Court of 18 March 2010, IV KZ 3/10, Lex/el. Judgment of the Supreme Court of 10 March 2011, V CSK 302/10, Lex/el. Compare with I. Nowak, Dokumenty urzędowe jako dowody w świetle procedury podatkowej, „Przegląd Podatków Lokalnych i Finansów Samorządowych” 2018, No 2, p. 20-27.

24 Judgment of the Supreme Court of 10 March 2011, V CSK 302/10, Lex/el.

25 Article 17 item 1-2 of Act on the court-appointed physician.
} 
free assessment of evidence the judicial bodies are not bound by certificates from court-appointed physicians, it seems reasonable that without expertise as to their assessment, they are required to take advantage of the experts' opinions ${ }^{26}$. In this respect, the position of the jurisprudence results from a judicial practice in which it is assumed that while not denying the right of the proceeding body to test the reliability of a certificate issued by a court-appointed physician, such assessment should not be discretionary, since the verification of the reliability of the certificate requires medical knowledge and, at the same time, it forces the competent judicial authorities to consult experts ${ }^{27}$. For example, in a judgment of 8 July 2015 the Supreme Court stated that "the position of a court-appointed physician on the possibility of the appearance of the examined person before the court is not binding on bodies, but it is a fundamental premise for the decision or lack of decision as to the justification for absence, and thus on the conduct of further procedural activities. The judicial body has the right to check the reliability of the issued certificate. However, the grounds for raising doubts about such reliability should be reasonable and justified by specific circumstances. If such doubts arise, they cannot be automatically resolved in a manner that is unfavourable to the party, but should be subject to appropriate verification" ${ }^{28}$. It is also worth noting that, according to judicature, firstly, it is not necessary for a person applying for a certificate from a court-appointed physician to have a sick leave, and secondly, there are no grounds for questioning the credibility of the certificate on the grounds that the court-appointed physician is not a specialist in reference to the illness which was adequate to the illness which he/she has stated. This "approach" of the proceeding bodies has no grounds in Act of 15 June 2007 on the court-appointed physician, because, in fact, it would limit the court-appointed physician in issuing certificates and impose on the person interested in obtaining a certificate an obligation impossible

\footnotetext{
M. Kurowski, Komentarz do art. 117 k.p.k..., Lex/el.

Decision of the Supreme Court of 14 May 2018, II KK 23/18, Lex/el.

Judgment of the Supreme Court of 8 July 2015, SDI 24/15, Lex/el.
} 
to fulfil to seek a court-appointed physician with a specialization corresponding to the probable cause of the patient's illness ${ }^{29}$.

On the basis of a statutory delegation, according to Article 15 paragraph 7 of the Court-Appointed Physician Act, the Minister of Justice in the regulation of 15 January 2018 specified the model for the certificate issued by a court-appointed physician confirming the ability or inability to appear on a summons or notice of the authorized body and model of issued certificates register ${ }^{30}$. It is worth noting that the certificate is of a technical and organizational nature, and it contains norms addressed to the court-appointed physician. Failure to meet the formal requirements set out in this regulation may result in sanctions provided for under Act on the court-appointed physician against the person issuing the certificate in the wrong form. These sanctions may in no case apply to the patient or affect the actual validity of the certificate issued in the perspective of procedural regulations, provided that such certificate contains information necessary to determine that the absence of the person should be regarded as justified on account of the illness diagnosed by a court-appointed phy$\operatorname{sician}^{31}$. Finally, the party to the proceedings cannot be charged with the control of the correct performance of the court-appointed physician duties assigned to them in accordance with the Regulation of the Minister of Justice of 15 January 2008 on the model of the certificate issued by the court-appointed physician and the model of issued certificates register ${ }^{32}$.

The court-appointed physician must draw up the register of issued certificates for each calendar month separately, together with the addition of any documents confirming the cost of transport to the location of the participant in the proceedings ${ }^{33}$. Moreover the register of the certificates

\section{Compare the decision of the Supreme Court of 14 May 2018, II KK 23/18, CBOSA.}

30

Ordinance of the Minister of Justice of 15 January 2008 on the model of the certificate issued by the court-appointed physician and the model of the register of the issued certificates - Dz.U. of 2008, No 14, poz. 86, with subsequent amendments.

31 Judgment of the Supreme Court of 11 June 2015, IV KK 56/15, Lex/el.

32 Ibidem.

33 § 3 items 2-3 of the Ordinance of the Minister of Justice of 14 January 2008 on remuneration of the court-appointed physician and mode of remuneration financing and repayment of travel costs, and the model of the register of issued certificates (consolidated text: Dz.U. of 2013, poz. 467, with subsequent amendments), hereinafter: MJO. 
issued by the court-appointed physician must contain, at the top of each page, the month and the year to which the register refers, and at the bottom of each page the date, signature, and stamp of the court-appointed physician, as well as: the ordinal number from the beginning of each month; date of issuence of the certificate; first name (names) and surname and the PESEL personal identification number or the date of birth (in the absence of a PESEL number) of the participant in the proceedings; name of the authorized body that issued the summons (notification) and reference number of the case; the amount of remuneration for issue of the certificate; the cost of travel to the location of the participant in the proceedings, and the total costs of the certificates issued ${ }^{34}$.

The court doctor keeps a register of issued certificates in writing ${ }^{35}$, separately for every calendar year, and after the year ends, in the event of a termination of the contract for the performance of the activities of a court-appointed physician, the court-appointed physician should immediately submit the register to the competent district court in which it should be stored for 15 years, counting from the end of the calendar year in which the register was handed over ${ }^{36}$.

The court-appointed physician is obliged to provide an access to the register of issued certificates at the request of a president of a district court, a court, or a prosecutor ${ }^{37}$. At the top of each completed page the register of issued certificates should contain the surname and names of the court-appointed physician, the court in the jurisdiction of which the activities of a court-appointed physician are performed, and the calendar year, while at the bottom of each completed page there should be the signature and stamp of the court-appointed physician ${ }^{38}$.

\footnotetext{
$\S 4$ item 1 point 1-7 MJO.

"The design of the register of issued certificates means that the court-appointed physician does not include any data from the history and physical examination, but only enters the statistical number of the disease causing the inability, which in practice excludes the possibility of verifying the content of the certificate" - Z. GąszczykOżarowski, Kontrola rzetelności zaświadczenia lekarza sq̨dowego, „Państwo i Prawo” 2012, No 11, p. 118.

Articles 15-16 of Act on the court-appointed physician.

Article 16 item 1 of Act on the court-appointed physician.

Article 15 items 3-4 of Act on the court-appointed physician.
} 
The register of issued certificates is subject to personal data protection provisions ${ }^{39}$. The entry in the register should include: the following: the number of the certificate issued; date of issue of the certificate; surname and first names of the participant in the proceedings and PESEL personal identification number or date of birth - in the absence of a PESEL number; the name of the authorized body that issued a request or a notification, and the reference number of the case; statistical number of the disease in accordance with the International Statistical Classification of Diseases and Related Health Problems; proof of the ability or inability to appear on summons or notice; specification of the reason for lack of personal examination of a participant in the case referred to in Article 12 item 4 of the Court-Appointed Physician Act; the name and address of the entity where the court-appointed physician got familiarised with the medical documentation of the participant in the proceedings or who made this documentation available, as well as information about the travel costs to the participant in the case referred to in article 12 item 3 of the CourtAppointed Physician Act.

\section{Court-appointed physician certificates financing rules}

The court-appointed physician is entitled to a remuneration for each certificate issued ${ }^{40}$ in the amount of PLN $100^{41}$. However, if it is necessary to travel to the location of a participant in the proceedings, the courtappointed physician is also entitled to a reimbursement of travel costs, according to terms set out in the provisions regarding employees of the state or local government for business travel within the country ${ }^{42}$. In ac-

Article 15 item 6 of Act on the court-appointed physician.

Article 18 item 1 of Act on the court-appointed physician.

$41 \S 2$ MJO.

42 Article 18 item 2 of Act on the court-appointed physician. If it is required for the court-appointed physician to travel to the location of the participant in proceedings using their own vehicle, the provisions of Regulation of the Minister of Infrastructure of 25 March 2002 on the rules for establishment and the method of reimbursement for the 
cordance with the Regulation of the Minister of Labour and Social Policy of 29 January 2013 on payments due to an employee of the state or local government by way of a business trip ${ }^{43}$ court-appointed physicians are entitled to, among other things, a reimbursement of travel, local transport commuting, an accommodation, and other required and documented expenses specified or recognized by the employer in accordance with justified needs ${ }^{44}$. As a side note it should be noted that the above Regulation does not differentiate the reimbursement on the basis of the courtappointed physician's form of employment, "therefore it must be held that reimbursement is also due if a contract of mandate is the basis for employment (entrusting of activities)" 45 . "The principle of freedom to conclude contracts can certainly be applied in relation to the contract on the performance of a court-appointed physician's activities"46, this is stated expressis verbis in Article 2 item 1 of the Court-Appointed Physician Act. It should also be emphasized that under current legal regulations a courtappointed physician is not an employee of a court, and therefore does not have an employment relationship with the president of a district court. One cannot forget that pursuant to Article 21 item 1 point $16 \mathrm{~b}$ of Act on personal income tax, the sustenance and other charges for the time of travel of a non-employee are free from income tax - up to the amount specified in separate legislation or in the regulations issued by the minister responsible for labour issues on the amount and the conditions determining payments due to an employee of a state or local government, for business travel within and outside the country (subject to item 13 of Article 21 of the above act).

use of private cars, motorcycles, and mopeds for business purposes - Dz.U. of 2002, No 27, poz. 271 with subsequent amendments.

43 Dz.U. of 2013, poz. 167, with subsequent amendments, hereinafter: MLSPR.

$44 \S 2$ item 2 MLSPR.

45 P. Ziółkowski, Czy lekarzowi sq̨dowemu należy się zwrot kosztów dojazdu z miejsca zamieszkania do miejscowości, w której przeprowadza badania uczestników postępowania (gabinetu, w którym dokonuje badań)?, Lex/el.

46 K. Flaga-Gieruszyńska, A. Klich, Ustawa..., (Komentarz do art. 4), Lex/el. 
The costs of issuing a certificate are financed from the state budget ${ }^{47}$ from the part at the disposal of the Minister of Justice, and in relation to military courts from the part at the disposal of the Minister of National Defence $^{48}$. Based on the statutory official travel provisions in Article 18 item 4 of Act on the court-appointed physician, the Minister of Justice, in agreement with the Minister of National Defence and the minister competent for health, determines, following a regulation of 14 January 2018 the amount of a remuneration for each certificate issued by a court-appointed physician, the procedure for financing remuneration and reimbursement of travel costs to the location of the participant in the proceedings, and a template for the register of issued certificates.

The register of issued certificates together with the relevant documents confirming the issue of the certificate and documents confirming the costs of travel to the location of the participant in the proceedings is forwarded in writing by the court-appointed physician to the financial management authority of the district court ${ }^{49}$. Then, within 14 days of a receipt of the above mentioned documents, the authority managing the finances of the district court confirms their correctness or indicates reservations, and applies for their supplementation or correction ${ }^{50}$. As a result, within 30 days from the date of receipt of all correctly prepared documents, the payment of remuneration and reimbursement of travel costs to the location of the participant in the proceedings takes place ${ }^{51}$.

On the basis of Article 19 item 1 of Act on court-appointed physicians the president of a district court, at the request of an authorized body ${ }^{52}$, may suspend the payment of a remuneration: firstly, in the event of reasonable doubts as to the reliability of the certificate issued by

\footnotetext{
This means that the patient does not pay any fee for a court-appointed physician visit.

Article 18 item 3 of Act on the court-appointed physician.

$\S 5$ item 1 MJO.

The court-appointed physician submits the corrected documents, together with the reason for them, within 7 days of receiving the documents to be supplemented or corrected $-\S 5$ item 2-3 MJO.

52 The authorized body shall immediately notify the president of the district court on the cessation or confirmation of circumstances resulting in the suspension of remuneration payment - Article 19 item 2 of Act on the court-appointed physician.
}

$51 \S 6 \mathrm{MJO}$. 
a court-appointed physician ${ }^{53}$, and secondly, if the certificate does not contain all the required elements ${ }^{54}$. In addition, in the event of the above mentioned circumstances referred to in Article 19 of Act on court-appointed physician, the president of the district court informs the financial unit of the district court about the suspension of remuneration payment, revocation of such suspension and revoking the right to remuneration ${ }^{55}$.

No remuneration is paid for the issue of a certificate confirming untruth as to the circumstances justifying the failure to appear, and, moreover, if there are reasonable doubts as to the reliability of the certificate issued by a court-appointed physician, the president of the district court may terminate the contract for the performance of activities of a courtappointed physician with immediate effect ${ }^{56}$. Moreover, the courtappointed physician can face criminal responsibility, because, prior to the conclusion of the court-appointed physician activities performance contract, the candidate for the post of a court-appointed physician is obliged, under Article 6 item 5 point 1 of Act on court-appointed physicians to make a statement to the president of the district court that she or he is aware of the criminal liability for certification of untruth. It is also worth noting that "there will certainly be civil liability towards a person who is injured if a court-appointed physician determines that they are able to participate in the proceedings and such participation results in the worsening of their health" ${ }^{37}$.

In accordance with the freedom of contracts existing in the scope of civil law, according to the collected empirical material, contracts with courtappointed physicians are concluded once for an indefinite period of time, usually allowing contract termination by the court-appointed physician with

53 "It is obvious that the concept of «reasonable doubt» should be interpreted with sufficient caution so that these contracts are not terminated on the basis of trivial premises, anecdotal statements, etc.” - K. Flaga-Gieruszyńska, A. Klich, Ustawa..., (Komentarz do art. 10), Lex/el.

54 Article 19 item 1 of the act on the court-appointed physician.

$\S 7$ MJO.

Article 10 and Article 20 of Act on the court-appointed physician.

57 K. Flaga-Gieruszyńska, A. Klich, Ustawa..., (Komentarz do art. 2), Lex/el. 
one month's, two months, ${ }^{58}$, three months ${ }^{59}$ or six months ${ }^{360}$ notice $^{61}$. Of course, contracts can be terminated earlier by mutual agreement.

\section{Taxation of the income achieved by court-appointed physicians with personal income tax}

The basic rule in force within the act on personal income tax is the principle of universality of taxation ${ }^{62}$ according to which all types of income are subject to taxation with income tax ${ }^{63}$, excluding ${ }^{64}$ :

1. exempt income - usually subject exemptions - pursuant to Article 21 of Act on the personal income tax;

2. income exempted pursuant to Articles 52 and 52a of Act on the personal income tax - temporary lay-off resulting from transitional provisions;

3. income exempted pursuant to Article 52c of Act on the personal income tax - exempt received by soldiers in connection with accommodation;

4. income exempted pursuant to Article 52d of Act on the personal income tax - compensations;

58 Yes, among others in the District Court in Legnica.

59 Yes, among others in the District Court in Siedlce, Olsztyn, Łomża, Białystok, Warszawa, Kalisz, Płock, Elbląg, Gliwice, Sieradz, Zielona Góra, and Wrocław.

60 Yes, among others in the District Court in Warszawa-Praga.

61 Monthly deadline was established among others in the District Court in Kielce, Częstochowa, Konin, Kraków, Nowy Sącz, Katowice, Bielsko-Biała, Suwałki, Tarnów, Lublin, and Rzeszów.

62 See Article 9 item 1 of Act on the personal income tax and W. Nykiel, K. Koperkiewicz-Mordel, Podatek dochodowy od osób fizycznych. Komentarz, Warszawa 2003, p. 52-53; I. Nowak, Matżeństwo a zwiqzzi partnerskie w świetle wybranych regulacji polskiego prawa podatkowego, „Kwartalnik Prawa Podatkowego” 2017, No 3, pp. 60-63; also judgment of the Voivodeship Administrative Court in Wrocław of 25 August 2016, I SA/Wr 537/16, CBOSA.

63 M. Kalinowski, Przedmiot podatku, Toruń 2013.

64 K. Koperkiewicz-Mordel, Podatek dochodowy od osób fizycznych [in:] M. Sęk (ed.), Prawo podatkowe. Podręcznik dla Podyplomowego Studium Prawa Podatkowego, vol. 2, Łódź 2014, p. 350. 
5. income from which, pursuant to the provisions of the Tax Code ${ }^{65}$ no tax was collected (this applies to situations in which the Minister of Finance pursuant to Article 22 of the Tax Code, by way of an ordinance, refrains from collecting the tax, in whole or in part, while also specifying the type of tax, the refrain concerned, the period of refrain, and taxpayer groups covered by the regulation) ${ }^{66}$;

6. categories of revenues, which according to Article 2 of Act on the personal income tax are exempt from personal income tax ${ }^{67}$.

In personal income tax, income is generally taxed, or more precisely, income earning ${ }^{68}$, i.e. the facts (behaviour or event) with which the tax act connects the rise, change or cessation of tax liability ${ }^{69}$. However, in some situations, the subject of taxation will be the revenue itself, excluding the costs of obtaining it. "This is owing to two circumstances: a) the desire to simplify the tax - when the revenues are relatively small, and b) the fear of tax evasion - especially in the case of occasional activities from which the income is taxable" ${ }^{\text {}}$.

In Article 10 of Act on personal income tax, the legislator categorizes revenues according to the source that creates them ${ }^{71}$. However, this cata-

65 Act of 29 August 1997 Tax Law (consolidated text: Dz.U. of 2019, poz. 900, with subsequent amendments).

66 J. Marciniuk (ed.), Podatek..., Legalis/el.

67 Zob. I. Nowak, Koszty uzyskania przychodów z praw autorskich przysługujq̨ce nauczycielom akademickim, „Toruński Rocznik Podatkowy” 2017/el, p. 165-197; Z. Kukulski, Rodzaje podatków [in:] W. Nykiel (ed.), M. Wilk (ed.), Zagadnienia ogólne prawa podatkowego, Łódź 2014, p. 84; W. Wójtowicz, Podatek dochodowy od osób fizycznych [in:] W. Wójtowicz (ed.), Zarys finansów publicznych i prawa finansowego, Warszawa 2011, p. 235.

68 A. Gomułowicz, J. Małecki, Ustawa o podatku dochodowym od osób fizycznych. Komentarz, Warszawa 2003, p. 95; K. Koperkiewicz-Mordel, Normatywne określenie przedmiotowego zakresu opodatkowania podatkiem dochodowym od osób fizycznych w Polsce [in:] M. Bogucka-Felczak, T. Nowak (ed.), Z teorii i praktyki prawa finansowego. Księga jubileuszowa dla Profesor Teresy Dębowskiej-Romanowskiej, Łódź 2014, p. 94.

69 Zieliński, Uproszczone formy opodatkowania dochodów osób fizycznych z działalności gospodarczej, Warszawa 2012, p. 57-58.

70 W. Wójtowicz, Podatek..., p. 238; analogicznie A. Bartosiewicz, Kubacki, PIT. Komentarz 2015, Lex/el.

71 I. Nowak, Opodatkowanie alimentów [in:] J.M. Łukasiewicz, I. Ramus (eds), Prawo alimentacyjne. Zagadnienia systemowe i proceduralne, vol. I, Toruń 2015, p. 202. 
logue is not of a numerus clausus nature (a closed catalogue), because the legislator establishes a separate category of revenues - from other sources - which allows for full taxation of all other categories of income ${ }^{72}$.

Establishment of the source of an income plays a crucial role, because depending on its type different calculation rules are in force, for example deductible expenses, or payment of the final amount of the tax due ${ }^{73}$. Nota bene "the separation of revenue sources is significant in at least two ways. Firstly, an assessment if the taxpayer achieved an income is made in relation to each source individually. Secondly, an income from individual sources is not taxed in the same way and the law provides for a number of differences" ${ }^{\prime 4}$.

In the light of the above considerations, it is justified to conclude that a remuneration for each certificate issued by a court-appointed physician who does not conduct business activity pursuant to Article 10 item 1 point 3 of Act on personal income tax must be classified as income from activities performed personally ${ }^{75}$, specifically pursuant to Article 13 point 6 of Act on personal income tax in connection with Article 10 item 2 of Act on personal income tax as the income of persons to whom a state or local government or administration, a court ${ }^{76}$ or the prosecutor, pursuant to the relevant provisions, commissioned specific activities, in particular the revenues of experts in court, investigation and administrative proceedings as well as payers, with reservation to Article 14 item 2 point 10, and col-

72 Therefore, the catalogue of sources of income regulated in article 10 of the act on the personal income tax is not of numerus clausus (closed list) nature because the legislator establishes a separate category of income - from other sources - to allow a full coverage of all other categories of revenue - A. Mariański, T. Miłek, Komentarz do art. 10 uopdof [in:] W. Nykiel, A. Mariański (eds), Komentarz do ustawy o podatku dochodowym od osób fizycznych, Gdańsk 2015, p. 168; I. Nowak, Glosa do wyroku Naczelnego Sq̨du Administracyjnego z dnia 28 października 2016, II FSK 2412/14, „Gdańskie Studia Prawnicze-Przegląd Orzecznictwa” 2017, No 3, p. 26.

73 J. Marciniuk (ed.), Podatek dochodowy od osób fizycznych. Komentarz 2017 (Komentarz do art. 10), Legalis/el.

74 A. Olesińska, Polskie prawo podatkowe, Toruń 2012, p. 272.

75 Article 10 item 1 point 2 of the act on the personal income tax.

76 Justice system in the Republic of Poland is held by the Supreme Court, common courts, administrative courts, and military courts - Article 175 item 1 of the Constitution of the Republic of Poland. 
lectors of public-law receivables, as well as an income from participation in committees appointed by state or local government authorities or administration, with the exception of the revenues referred to in point $9^{77}$. The consequence of such classification of revenue are the obligations specified in section 7 of the personal income tax act titled "Collection of tax or tax advances by payers" that rest upon the district courts as the payers $^{78}$. Therefore, it should be assumed that it follows from Article 13 item 6 of the income tax act that the condition for recognizing the benefits received by a person performing activities ordered by the court as income from activities carried out personally is that the authority of the entity ordering the performance of such activities results from provisions of the $\operatorname{law}^{79}$. In the present case, such provisions are undoubtedly included in Act on the court-appointed physician, according to which the basis for obtaining income (remuneration) by a court-appointed physician is a concluded civil-law agreement (a mandate contract) with the president of the district court on performance of activities of a court-appointed physician who issues certificates confirming the ability or inability to appear on a summons or to notify the authorized body of participants in proceedings due to illness, within the area of jurisdiction of the given district court.

If the court-appointed physician declares to the president of the competent district court that he performed activities related to the issue of certificates within the scope of his non-agricultural business activity, then the district court will not act as a payer ${ }^{80}$, and thus not be obliged to

77 According to Article 13 point 9 of Act on the personal income tax revenues obtained on the basis of business management contracts, managerial contracts or contracts of a similar nature, including revenues from such contracts concluded as part of a nonagricultural business operated by the taxpayer - with the exception of the revenues referred to in point 7 (revenues received by persons, irrespective of the method of their appointment, belonging to the boards, supervisory boards, committees or other bodies constituting legal persons).

78 Resolution of the Supreme Administrative Court of 21 October 2013, II FPS 1/13, CBOSA.

79 Ibidem; judgment of the Voivodeship Administrative Court in Gliwice of 12 January 2010, I SA/Gl 670/09, CBOSA.

80 See I. Nowak, Pozycja podatkowoprawna płatnika w świetle jego odpowiedzialności za zobowiqzania podatkowe [in:] K. Flaga-Gieruszyńska, E. Cała-Wacinkiewicz, D. Wacinkiewicz, Bezpieczeństwo jako podstawowa potrzeba człowieka. Zbiór stu- 
charge personal income tax advance payments ${ }^{81}$. Then the court-appointed physician will be obliged to pay advances on personal income tax as part of taxation of income obtained from operated business activity ${ }^{82}$.

\section{Summary}

The Court-Appointed Physician Act, in force, with few exceptions, from 1 February 2008 requires several "legal adjustments". Firstly, one of its major drawbacks is the fact that it does not cover the scope of administrative court proceedings ${ }^{83}$. The provisions of the act on proceedings before administrative courts do not require the presentation of a certificate confirming inability to appear at the hearing issued by a court-appointed physician in order to justify failure to appear due to illness, because they do not contain the equivalent of article $214^{1}$ of the Civil Proceedings Code ${ }^{84}$ or article $117 \S 2 \mathrm{a}$ of the Criminal Proceedings Code ${ }^{85}$, added to the content of the above acts respectively by Articles 21 and 24 of the Court-

diów, Gorzów Wielkopolski 2014, p. 251 and seq.; id. Wina podatnika jako negatywna przesłanka wyłq̨czajqca odpowiedzialność podatkowq płatnika, „Przegląd Prawa Publicznego" 2014, No 1, p. 50 and seq.

81 Judgment of the Supreme Administrative Court of 30 November 2011, II FSK 1009/10, CBOSA; compare with a letter of the Minister of Finance of 4 September 2002, PB5/KD-033-317-2122/02, Lex/el.

82 Article 44 of Act on the personal income tax.

83 Judgment of the Voivodeship Administrative Court in Gliwice of 2 March 2012, III SA/Gl 546/11, CBOSA.

84 Justification of a failure to appear due to illness of the parties, their legal representatives, proxies, witnesses, and other participants in the proceedings requires the presentation of a certificate confirming the impossibility of appearing at the summons or notification of the court issued by a court-appointed physician. However, the provision of $\S 1$ shall not apply to persons deprived of their liberty, whose excuse for failure to appear due to illness is regulated by separate provisions (§ 2$)$.

85

Justification of a failure to appear due to illness of the accused, witnesses, defenders, proxies, and other participants in the proceedings, whose presence was obligatory or who applied for admission to the act, being entitled to take part in it, requires the presentation of a certificate confirming the inability to appear on call or notification to the authority conducting the proceedings, issued by a court-appointed physician. However, the provision of $\S 2$ a shall not apply to persons deprived of their liberty whose principles of justifying their absence are governed by separate provisions ( $§ 5$ ). 
Appointed Physician Act ${ }^{86}$. Taking, therefore, into account, among other principles, the principle of legal system consistency and the rational legislator paradigm, there are no rational reasons for the exclusion of administrative courts proceedings from $\mathrm{it}^{87}$. In this regard a de lege ferenda request should be made for the extension of the Court-Appointed Physician Act with court administrative proceedings ${ }^{88}$. Also, according to the doctrine, as part of a single "legal mechanism" it is necessary to "create a uniform system of justification of absence in individual court proceedings" ${ }^{\text {89 }}$, as the Court-Appointed Physician Act was introduced precisely to dispel doubts of the court as to the authenticity of issued sick leaves ${ }^{90}$.

Secondly, an electronic register of the issued certificates should be introduced, since the current form of a written one is heavily "outdated" and "limits the informative and security function of the register, the implementation of which is nowadays impossible to imagine without the effective use of IT systems" ${ }^{\text {, }}$.

Thirdly, the obligation of keeping a list of the court-appointed physicians in electronic form and its provision at the website of a district court

86 Judgment of the Supreme Administrative Court of 23 January 2013, I OSK 1208/12, CBOSA.

87 According to Article 184 of the Constitution of the Republic of Poland, the Supreme Administrative Court and other administrative courts exercise, within the scope specified in the act, the control of public administration activities. In addition, "the context in which article 176 item 1 of the Constitution, on the other hand, orders to assume that the term "judicial proceedings" used in it should be combined with the competence that the Constitution has reserved for the courts, i.e. the administration of justice (article 175 (1) of the Constitution)" - P. Grzegorczyk, Glosa do wyroku TK z dnia 27 marca 2007, SK 3/05, „Przegląd Sądowy” 2007, No 11-12, p. 190 and the following. In other words, Article 175 of the Constitution differentiates various branches of the general and administrative judiciary - judgment of the Supreme Administrative Court of 5 February 2008, I OSK 581/07, Lex nr 355665; more in I. Nowak, A. Krajewska, Doradca podatkowy jako profesjonalny pełnomocnik w postępowaniu sq̨dowoadministracyjnym [in:] D. Gil, E. Kruk (eds), Role uczestników postępowań sq̨dowych wczoraj, dziś i jutro, vol. 2, Lublin 2015, pp. 261-284.

88 T. Wiśniewski, Opinia o projekcie ustawy o lekarzu sq̨dowym (druk 1568) z dnia 16 kwietnia 2007, http://orka.sejm.gov.pl/rexdomk5.nsf/Opwsdr?OpenForm\&1568.

89 Ibidem.

90 Judgment of the Voivodeship Administrative Court in Warszawa of 31 May 2012, I SA/Wa 2312/11, CBOSA.

91 K. Flaga-Gieruszyńska, A. Klich, Ustawa..., (Komentarz do art. 8), Lex/el. 
should be regulated - as a rule, and not, as is the case today, that such a list may be kept in electronic form only as an addition ${ }^{92}$.

Fourthly, the Court-Appointed Physician Act "in its present form" is one of the causes of the "disability" of the Polish system of justice. The deficit of court-appointed physicians in Poland, caused mainly by low remuneration offered for their work, leads to the prolongation of court proceedings $^{93}$. One should not forget that only court-appointed physicians included on the court-appointed physicians list for the district court appropriate for the location of the participant in the proceedings can issue certificates $^{94}$. A contrario, each of the certificates submitted by a participant in the proceedings, and issued by the court-appointed physician appropriate for a different district court, in accordance with Article 12 item 2 of the Court-Appointed Physician Act, does not justify their absence, as it shall be considered as issued in excess of the powers and coming from an unauthorized person ${ }^{95}$.

For example: the President of the District Court in Ostrołęka has no contracts concluded with court-appointed physicians owing to the lack of - as he put it - "applications of physicians for the possibility of concluding such contracts" ${ }^{96}$. In addition, the number of court-appointed physicians performing the statutory obligations within the area of district courts is low, all the more because they are physicians of various specializations. As a result, difficulties with the actual availability of the court-appointed physicians of specific specializations causes the prolongation of court proceedings, and also generates redundant costs. For example: within the area of jurisdiction of the District Court in:

92 Compare article 8 item 2 of Act on the court-appointed physician.

93 Compare M. Stelmach, Zaliczka nie rozwiqże problemu braku biegłych lekarzy sq̨dowych, https://www.prawo.pl/zdrowie/biegli-lekarze-sadowi-zaliczka-nie-rozwiaze-problemuich-braku,419377.html.

94 Article 12 item 2 of Act on the court-appointed physician.

95 Compare judgment of the District Court in Sieradz of 8 May 2019, II Ka 79/19, Lex/el.

96 Information of the President of the District Court in Ostrołęka of 30 July 2019, No Adm. 424-46/19. 
1. Piotrków Trybunalski - there are 9 court-appointed physicians ${ }^{97}$,

2. Katowice, Częstochowa, Wrocław -8 court-appointed physicians ${ }^{98}$;

3. Koszalin -7 court-appointed physicians ${ }^{99}$;

4. Jelenia Góra -6 court-appointed physicians ${ }^{100}$;

5. Bydgoszcz, Elbląg - 5 court-appointed physicians ${ }^{101}$,

6. Toruń, Nowy Sącz - 4 court-appointed physicians ${ }^{102}$;

7. Kalisz, Sieradz, Płock -3 court-appointed physicians ${ }^{103}$,

8. Rzeszów, Bielsko-Biała - 2 court-appointed physicians ${ }^{104}$,

9. Zielona Góra, Suwałki - 1 court-appointed physician ${ }^{105}$.

As a side note, it is worth noting that the Ministry of Justice undertakes no actions in the above mentioned province. The information obtained from the Director of the Department of Personnel and Organization of Common and Military Courts at the Ministry of Justice shows that the Ministry of Justice does not even have a list of court-appointed physicians with their specializations and a division into areas of competence of district courts in Poland (sic!) ${ }^{106}$.

97 https://www.piotrkow-tryb.so.gov.pl/container/informacje-dla-interesantow/lekarze/ lekarze-strona.pdf.

98 https://www.katowice.so.gov.pl/download/wykaz-lekarzy-sadowych.pdf;

https://www.czestochowa.so.gov.pl/download/lista-lekarzy-sadowych-01-08-2019r.pdf; www.wroclaw.so.gov.pl/documents/Informacje/Lekarze/2018/20180924_lista_lekarzy _20180924.pdf, (access on-line: 25.08.2019).

99 https://koszalin.so.gov.pl/wykaz-lekarzy-sadowych,new,m2,269,258.html,190, (access on-line: 25.08.2019).

100 http://www.jelenia-gora.sr.gov.pl/download/wykaz-lekarzy-sadowych---2018-rok1517477243.pdf, (access on-line: 25.08.2019).

101 http://bip.bydgoszcz.so.gov.pl/artykuly/63/lekarze-sadowi, (access on-line: 25.08.2019).

102 https://so.torun.pl/download/lekarze-sadowi-12.08.2019.pdf; https://www.nowy-sacz.so.gov.pl/container/lekarze//wykaz-lekarzy-sadowych---nowysacz-aktualne2019-3.pdf, (access on-line: 25.08.2019).

103 http://www.kalisz.so.gov.pl/index.php?id=181\&id2=106; http://www.sieradz.so.gov.pl/site/lekarze-sadowi-38, (access on-line: 25.08.2019).

104 https://rzeszow.so.gov.pl/sites/default/files/2019-07/Wykaz\%20Lekarzy\%20S\%C4\% 85dowych\%20z\%20dnia\%209\%20July\%202019\%20r.pdf, (access on-line: 25.08.2019).

105 https://www.zielona-gora.so.gov.pl/?mod=100; https://bip.suwalki.so.gov.pl/lekarzesadowi,197.html, (access on-line: 25.08.2019).

106 Information of the Director of the Human Resources and Organization of Common and Military Courts Department at the Ministry of Justice of 31 July 2019, No DKOV.082.15.2019. 
Fifthly, keep in mind that if the party to the proceedings residing abroad cannot attend the summons of an authorised body owing to an illness, it cannot be expected to deliver the request for adjournment with a certificate issued by a Polish court-appointed physician ${ }^{107}$. It is enough to submit a foreign medical certificate to substantiate the circumstances justifying postponing of the hearing ${ }^{108}$.

Sixthly - as a de lege lata request - the contracts concluded by presidents of district courts with court-appointed physicians should not include the amount of their remuneration ${ }^{109}$, since it is determined on the basis of a secondary legislation to the Court-Appointed Physician Act and depends on the number of performed services (certificates issued by the courtappointed physician $)^{110}$. As a side note, it should be noted that such legal situation is a kind of exception, because in the case of lay judges, court experts, sworn translators, professional probation officers, or ex officio lawyers, the authorized body does not conclude this type of contract: they are all appointed for pending court proceedings ${ }^{111}$.

107 Judgment of the Supreme Court of 28 June 2017, IV KK 468/16, Lex nr 2350668; A. Partyk, Strona chorująca za granica nie ma „dojścia” do lekarza sq̨dowego 2017, Lex/el.

108 Ibidem.

109 Such provisions can be found, among others, in contracts concluded by the President of the District Court in Tarnów (information of 7 August 2019, No Adm.-0144-47/19), the President of the District Court in Suwałki (information of 7 August 2019, No A-060-42/19), the President of the District Court in Elbląg (information of 7 August 2019, No OA.0132.71.2019), the President of the District Court in Warszawa (information of 5 August 2019, No BEZP-0153-775/19), the President of the District Court in Katowice (information of 5 August 2019, No Prez.008-286/19), the President of the District Court in Szczecin (information of 12 August 2019, No Adm-028-112/19), the President of the District Court in Kielce (information of 9 August 2019, No Adm0144-154/19), the President of the District Court in Siedlce (information of 30 July 2019, A-0151-57/19), the President of the District Court in Zamość (information of 30 July 2019, No Adm-061-60/19), the President of the District Court in Konin (information of 31 July 2019, OA-062-48/19); the President of the District Court in Gorzów Wielkopolski (information of 1 August 2019, No A-052-250/2019), the President of the District Court in Nowy Sącz (information of 2 August 2019, No A-0144-53/19).

110 Individual interpretation of the Director of the Tax Chamber in Bydgoszcz of 18 May 2009, No ITPB1/415-367/09/DP.

111 Individual interpretation of the Director of the Tax Chamber in Katowice of 5 May 2011, No IBPBII/1/415-126/11/HK. 
Seventhly - within de lege lata request - one should remember that the personal income tax act does not regulate specifically the revenues generated by court-appointed physicians. Therefore, the classification of revenues obtained by court-appointed physicians to a specific source specified in Article 10 of the personal income tax act is of elementary significance $^{112}$. Not without reason it is indicated in the literature and judicial decisions, that determination of the source from which the income achieved by the taxpayer comes, is of great practical importance, as it determines the further procedure in the administration of personal income tax, for example in the scope of and mode of later duties of the taxpayer or the passive entity of the tax-law relationship ${ }^{113}$. To summarise, revenues achieved by court-appointed physicians from the remuneration for each issued certificate confirming the ability or inability to appear at the summons or notification of the authorized body of participants in proceedings due to illness in the area of jurisdiction of a given district court should be classified as:

1. an income from activity performed personally (Article 13 item 6 of the personal income tax act in connection with Article 10 item 1 point 2 of the personal income tax act),

2. an income from non-agricultural business activities (Article 10 item 1 point 3 of the personal income tax act) - if the court-appointed physician declares that his/her activities related to the issue of certificates is included in the scope pursued by their business.

From empirical material obtained from the presidents of district courts in Poland, it follows that, as a rule, all these budget units correctly qualify the revenues generated by court-appointed physicians (activities carried out in person or non-agricultural business activity). However, the "actions" of several district courts are doubtful ${ }^{114}$, as they involve qualifi-

112 Compare with an email information obtained from the National Tax Administration of 13 August 2019, No 0110.KIZ.4110.14909.2019.

113 I. Nowak, Koszty..., p. 170; judgment of the Supreme Administrative Court of 25 May 2017, II FSK 1034/15, CBOSA.

114 So, e.g. the District Court in Legnica (according to information obtained from the court's President on 8 August 2019, No A-061-54/19); the District Court in Suwałki (according to information obtained from the court's President on 7 August 2019, No 
cation of revenues generated by the court-appointed physicians correctly as income from a personally performed activity (Article 10 item 2 of the personal income tax act), but in our opinion it is incorrectly connected to Article 13 item 8 of the personal income tax act ${ }^{115}$. Such a qualification should be regarded as contra legem, because Article 13 item 6 of the personal income tax act in connection with Article 10 item 1 point 2 of the personal income tax act is the appropriate provision. Also one cannot in any way endorse the position, according to which a district court is collecting a personal income tax advance from the salaries of court-appointed physicians operating their own business ${ }^{116}$.

\section{Bibliography:}

Artymiak G., Sqqdy okręgowe [in:] P. Hofmański, Z. Kwiatkowski (eds), System Prawa Karnego Procesowego. Tom V. Sqdy i inne organy postępowania karnego 2015, Lex/el.

Bartosiewicz A., Kubacki R., PIT. Komentarz 2015, Lex/el.

Flaga-Gieruszyńska K., Klich A., Ustawa o lekarzu sq̨dowym. Komentarz 2013, Lex/el.

Gąszczyk-Ożarowski Z., Kontrola rzetelności zaświadczenia lekarza sq̨dowego, „Państwo i Prawo” 2012, No 11, pp. 112-119.

Gomułowicz A., Małecki J., Ustawa o podatku dochodowym od osób fizycznych. Komentarz, ABC, Warszawa 2003.

A-060-42/19); the District Court in Torun (according to information obtained from the court's President on 8 August 2019, No A-065-67/19).

115 The following are considered as revenues from activities carried out personally, referred to in Article 10 item 1 point 2: revenues from the provision of services, based on a mandate contract or a specific task contract, obtained only from:

1. a natural person conducting business activity, a legal person and its organizational unit, and an organizational unit without legal personality,

2. the owner (holder) of a property at which premises are rented, or the supervisor or administrator acting on their behalf - if the taxpayer performs these services solely for the purposes related to such property,

3. inherited enterprises

- with the exception of revenues obtained on the basis of contracts concluded as part of a non-agricultural business activity carried out by the taxpayer and the revenues referred to in point 9.

116 Information obtained from the President of the District Court in Jelenia Góra of 26 August 2019, A-061-60/19. 
Grzegorczyk P., Glosa do wyroku TK z dnia 27 marca 2007, SK 3/05, „Przegląd Sądowy” 2007, No 11-12, pp. 190-204.

Kalinowski M., Przedmiot podatku, TNOiK, Toruń 2013.

Knoppek K., Dowód z opinii biegłego [in:] Ereciński T., Wiśniewski T. (eds), System Prawa Procesowego Cywilnego. Tom II. Część II. Postępowanie procesowe przed sqdem pierwszej instancji 2016, Lex/el.

Koperkiewicz-Mordel K., Podatek dochodowy od osób fizycznych [in:] M. Sęk (ed.), Prawo podatkowe. Podręcznik dla Podyplomowego Studium Prawa Podatkowego, vol. 2, UŁ, Łódź 2014.

Koperkiewicz-Mordel K., Normatywne określenie przedmiotowego zakresu opodatkowania podatkiem dochodowym od osób fizycznych w Polsce [in:] M. Bogucka-Felczak, T. Nowak (ed.), Z teorii i praktyki prawa finansowego. Księga jubileuszowa dla Profesor Teresy Dębowskiej-Romanowskiej, UŁ, Łódź 2014.

Kukulski Z., Rodzaje podatków [in:] W. Nykiel, M. Wilk (eds), Zagadnienia ogólne prawa podatkowego, CDiSP, Łódź 2014.

Kurowski M., Komentarz do art. 117 k.p.k. [in:] Świecki D. (ed.), Kodeks postępowania karnego. Tom I. Komentarz aktualizowany 2019, Lex/el.

Marciniuk J. (ed.), Podatek dochodowy od osób fizycznych. Komentarz 2017, Legalis/el.

Mariański A., Miłek T., Komentarz do art. 10 of the act on the personal income tax. [in:] W. Nykiel, A. Mariański (eds), Komentarz do ustawy o podatku dochodowym od osób fizycznych, ODDK, Gdańsk 2015.

Nowak I., Dokumenty urzędowe jako dowody w świetle procedury podatkowej, „Przegląd Podatków Lokalnych i Finansów Samorządowych” 2018, No 2, pp. 20-27.

Nowak I., Małżeństwo a zwiq̨zki partnerskie w świetle wybranych regulacji polskiego prawa podatkowego, „Kwartalnik Prawa Podatkowego” 2017, No 3, pp. 55-83.

Nowak I., Glosa do wyroku Naczelnego Sqdu Administracyjnego z dnia 28 października 2016, II FSK 2412/14, „Gdańskie Studia Prawnicze-Przegląd Orzecznictwa” 2017, No 3, pp. 25-38.

Nowak I., Koszty uzyskania przychodów z praw autorskich przysługujq̨ce nauczycielom akademickim, „Toruński Rocznik Podatkowy” 2017/el, pp. 165-197.

Nowak I., Krajewska A., Doradca podatkowy jako profesjonalny pełnomocnik w postępowaniu sqdowoadministracyjnym [in:] D. Gil, E. Kruk (eds), Role 
uczestników postępowań sq̨dowych - wczoraj, dziś i jutro, vol. 2, KUL, Lublin 2015.

Nowak I., Opodatkowanie alimentów [in:] J.M. Łukasiewicz, I. Ramus (eds), Prawo alimentacyjne. Zagadnienia systemowe i proceduralne, vol. I, TNOiK, Toruń 2015.

Nowak I., Wina podatnika jako negatywna przesłanka wyłączajq̨ca odpowiedzialność podatkowq płatnika, „Przegląd Prawa Publicznego” 2014, No 1, pp. 50-59.

Nowak I., Pozycja podatkowoprawna płatnika w świetle jego odpowiedzialności za zobowiqzzania podatkowe, [in:] K. Flaga-Gieruszyńska, E. CałaWacinkiewicz, D. Wacinkiewicz, Bezpieczeństwo jako podstawowa potrzeba człowieka. Zbiór studiów, PWSZ, Gorzów Wielkopolski 2014.

Nykiel W., Koperkiewicz-Mordel K., Podatek dochodowy od osób fizycznych. Komentarz, LexisNexis, Warszawa 2003.

Olesińska A., Polskie prawo podatkowe, TNOiK, Toruń 2012.

Partyk A., Strona chorujq̨ca za granicq nie ma „dojścia” do lekarza sqdowego 2017, Lex/el.

Stelmach M., Zaliczka nie rozwiq̨że problemu braku biegłych lekarzy sq̨dowych, https://www.prawo.pl/zdrowie/biegli-lekarze-sadowi-zaliczka-nie-rozwiazeproblemu-ich-braku,419377.html.

Wiśniewski T., Opinia o projekcie ustawy o lekarzu sq̨owym (druk 1568) z dnia 16 kwietnia 2007, http://orka.sejm.gov.pl/rexdomk5.nsf/Opwsdr?OpenForm\&1568.

Wójtowicz W. (ed.), Zarys finansów publicznych i prawa finansowego, Wolters Kluwer, Warszawa 2011.

Zieliński, Uproszczone formy opodatkowania dochodów osób fizycznych z działalności gospodarczej, OPP, Warszawa 2012.

Ziółkowski P., Czy lekarzowi sq̨dowemu należy się zwrot kosztów dojazdu z miejsca zamieszkania do miejscowości, w której przeprowadza badania uczestników postępowania (gabinetu, w którym dokonuje badań)?, Lex/el. 